\title{
Haushaltspolitik der neuen Bundesregierung
}

Die neue Bundesregierung aus SPD, Bündnis 90/Die Grünen und FDP hat im Koalitionsvertrag ein „Jahrzehnt der Zukunftsinvestitionen“ in Aussicht gestellt. Bereits im Vorfeld der Koalitionsverhandlungen wurde kontrovers über die finanzpolitischen Möglichkeiten und Spielräume diskutiert. Die Vorhaben der neuen Koalition - Schuldenbremse einhalten, Reform der Grundsicherung, keine Steuererhöhungen, grüne Investitionen - waren dabei häufig als „Quadratur des Kreises“ gesehen worden. Die Autor:innen des Zeitgesprächs diskutieren, ob die im Koalitionsvertrag genannten Finanzierungsinstrumente geeignet sind, um die zentralen finanzpolitischen Herausforderungen in den kommenden Jahren zu bewältigen, und wie die Haushaltspläne mit der Schuldenbremse sowie den fiskalischen Regeln auf EU-Ebene in Einklang gebracht werden können.

Finanzierung von Zukunftsinvestitionen: Pragmatische Lösungen sind gefragt

Monika Schnitzer, Ludwig-Maximilians-Universität München; Mitglied des Sachverständigenrates zur Begutachtung der gesamtwirtschaftlichen Entwicklung.

Achim Truger, Universität Duisburg-Essen; Mitglied des Sachverständigenrates zur Begutachtung der gesamtwirtschaftlichen Entwicklung.

(Un-)konventionelle Methoden zur Finanzierung der Ampelpläne

Jens Südekum, Düsseldorf Institute for Competition Economics der Heinrich-Heine-Universität Düsseldorf.

Berlin sieht es locker - Brüssel (noch) nicht

Jens Boysen-Hogrefe, Kiel Institut für Weltwirtschaft; Christian-Albrechts-Universität zu Kiel.

Not kennt kein Gebot? Sondervermögen als Speicher von Notlagenkrediten

Thiess Büttner, Friedrich-Alexander-Universität Erlangen-Nürnberg; Vorsitzender des Beirats des Stabilitätsrats und Mitglied im Wissenschaftlichen Beirat beim Bundesministerium der Finanzen.

Kommunen zentral für Jahrzehnt der Zukunftsinvestitionen

Katja Rietzler, Institut für Makroökonomie und Konjunkturforschung in der Hans-Böckler-Stiftung (IMK), Düsseldorf.

Title: Budget Policy of the New Federal Government

Abstract: The new federal government of SPD, Bündnis 90/Die Grünen and FDP has promised a "decade of future investments" in its coalition agreement. Already in the run-up to the coalition negotiations, there were controversial discussions about the fiscal policy options and room for manoeuvre. The red lines of the new coalition partners - adherence to the debt brake, reform of basic security, no tax increases, green investments - were often seen as "squaring the circle". The authors discuss whether the financing instruments mentioned in the coalition agreement are suitable for coping with the central fiscal challenges in the coming years and how the budgets can be brought into line with the debt brake and the fiscal rules at the EU level. 